\title{
SYMBIOTIC EFFICIENCY OF INOCULATION WITH NITROGEN-FIXING BACTERIA AND ARBUSCULAR MYCORRHIZAL FUNGI IN Tachigali vulgaris SEEDLINGS
}

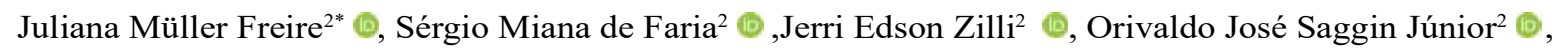
Isabel Silveira Camargo ${ }^{3} \bullet$, Janaína Ribeiro Costa Rouws $^{2} \odot$ and Ederson da Conceição Jesus ${ }^{2}$

\footnotetext{
${ }^{1}$ Received on 10.01.2019 accepted for publication on 09.03.2020.

${ }^{2}$ Empresa Brasileira de Pesquisa Agropecuária, Seropédica, RJ-Brasil. E-mail: <juliana.muller@embrapa.br $>$, <sergio.defaria@embrapa. br>, <jerri.zilli@embrapa.br>, <orivaldo.saggin@embrapa.br>, <janaina.rouws@embrapa.br $>$ and <ederson.jesus@embrapa.br>. ${ }^{3}$ Universidade Federal Rural do Rio de Janeiro, Engenheira Florestal, Seropédica, RJ-Brasil . E-mail: <isabel_eco@terra.com.br>. ${ }^{*}$ Corresponding author.
}

\begin{abstract}
The present study aimed to evaluate the effect of inoculation with nitrogen-fixing bacteria (NFB) and arbuscular mycorrhizal fungi (AMF) on the development of Tachigali vulgaris seedlings under nursery conditions. The seedlings were produced in $1 \mathrm{~kg}$ bags on a substrate of sand and vermiculite $(1: 1)$, following a completely randomized experimental design in a 3 (NFB) x 2 (with and without AMF) factorial scheme with 3 additional control treatments consisting of: seedlings inoculated only with AMF (mycorrhizal control), noninoculated seedlings fertilized with $\mathrm{N}$ (nitrogenized control) and without $\mathrm{N}$ (absolute control). The following variables were evaluated: height, stem diameter (SD), shoot dry mass (SDM), root dry mass (RDM) and nodule dry mass (NDM), P accumulation in the shoot, and root mycorrhizal colonization (RMC). Efficiency and effectiveness were calculated to evaluate the plant response to double inoculation. The treatments showed a significant effect for all variables, except for mycorrhizal colonization, nodule number, and dry mass, with the nitrogen treatment having the highest growth values. Plants submitted to double inoculation showed a higher accumulation of dry matter, height and SD, reaching a 124\% higher RDM regarding the absolute control, $90 \%$ more SDM, and $207 \%$ more NDM regarding the seedlings inoculated only with rhizobia. The positive effect of double inoculation occurred regardless of the strain used. The results indicate that the joint inoculation of NFB and AMF was beneficial for the species, promoting its growth.
\end{abstract}

Keywords: Symbiosis, Biological nitrogen fixation, Recovery of degraded areas.

\section{EFICIÊNCIA SIMBIÓTICA DA INOCULAÇÃO COM BACTÉRIAS FIXADORAS DE NITROGÊNIO E FUNGOS MICORRÍZICOS ARBUSCULARES EM MUDAS DE}

\author{
Tachigali vulgaris
}

\begin{abstract}
RESUMO -O presente estudo teve como objetivo avaliar o efeito da inoculação com bactérias fixadoras de nitrogênio (BFNs) e fungos micorrizicos arbusculares (FMAs) no desenvolvimento de mudas de Tachigali vulgaris em condições de viveiro. As mudas foram produzidas em sacos de $1 \mathrm{~kg}$ em substrato areia e vermiculita (1:1), seguindo delineamento experimental inteiramente casualizado, em esquema fatorial 3 (BFNs) $x 2$ (com e sem FMAs), com 3 tratamentos testemunhas adicionais consistindo de mudas inoculadas apenas com os FMAs (testemunha micorrizada), mudas não inoculadas fertilizadas com $N$ (testemunha nitrogenada) ou sem $N$ (testemunha absoluta). As seguintes variáveis foram avaliadas: altura, diâmetro a altura do colo (DAC), massa seca de parte aérea (MSPA), raizes (MSR) e nódulos (MSN), acúmulo de P na parte aérea e colonização micorrízica (CM) das raizes. Calculou-se a eficiência e a eficácia para avaliar a resposta das plantas à dupla inoculação. Os tratamentos demonstraram efeito significativo para todas as variáveis, com exceção de colonização micorrízica, número e massa de nódulos secos, sendo o tratamento nitrogenado o que apresentou os maiores valores de crescimento. Plantas submetidas à dupla inoculação apresentaram maior acúmulo de matéria seca, altura e DAC, alcançando MSR 124\% maior em relação à testemunha absoluta, 90\% mais MSPA
\end{abstract}

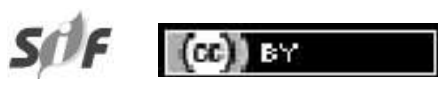

Revista Árvore 2020;44:e4424

http://dx.doi.org/10.1590/1806-908820200000024 


\begin{abstract}
e 207\% mais MSN em relação às mudas inoculadas somente com rizóbio. O efeito positivo da dupla inoculação ocorreu independente da estirpe utilizada. Os resultados indicam que a inoculação conjunta de BFNs e FMAs foi benéfica para a espécie, promovendo o seu crescimento.
\end{abstract}

Palavras-Chave: Simbiose, Fixação biológica de nitrogênio, Recuperação de áreas degradadas.

\section{INTRODUCTION}

Several forest planting methodologies have been adopted to recover degraded areas, among which the use of nitrogenfixing bacteria (NFB) and arbuscular mycorrhizal fungi (AMF) in mutualistic symbiosis with legumes is highlighted (Chaer et al., 2011). NFB can supply a plant with 60 to $100 \%$ of its nitrogen needs when in symbiosis, which can reach up to $600 \mathrm{~kg}$ of $\mathrm{N}$ ha $^{-1}$ per year (Peoples et al., 2009; Döbereiner, 1984). Such an association offers economic and ecological advantages when dispensing with the use of nitrogen fertilizers, which imply in large consumption of fossil fuels to reach the necessary temperatures and pressure in order to be industrially produced by the Haber-Bosch process (Travis, 2017).

Another very common symbiotic association not only in the Leguminosae family is with AMF, which possess a most striking beneficial effect in increasing the absorption surface and extension of the root system, thereby enhancing the absorption of nutrients, especially those less mobile in the soil such as phosphorus, zinc and copper (Saggin-Junior and Silva, 2005). The results are more nourished, hydrated and vigorous plants which are more resistant to adverse environmental conditions and pathogens and pests, with differentiated competitiveness in the field (Wagg et al., 2011). This constitutes a relevant factor in the tropics where low fertility soils predominate (Smith and Smith, 2011).

AMF can promote a synergistic effect with NFB in tripartite symbiosis (fungus-plant-bacteria), resulting in greater legume growth when there is a triple association (Bournaud et al., 2018). In addition, the tripartite association has been recognized for its ability to bioremediate contaminated soils, enabling the growth of legumes which will assist by exuding degrading enzymes from persistent organic pollutants (Faria et al., 2017).

Selecting NFB and AMF strains which are symbiotically efficient is of fundamental importance for the recovery technology of degraded areas to be effective due to the fact that many tree legumes have high nodulation specificity (Marques et al., 2001; Chaer et al., 2011) and symbiotic compatibility with AMF (Pouyu-Rojas et al., 2006).

Double inoculation with mycorrhizal fungi and rhizobial strains has been successfully tested for several native forest legumes, however, the experiments in most studies which have evaluated the efficiency of this tripartite symbiosis are conducted in pots with soil in sterile conditions, with a minority of works which have evaluated this interaction in nursery or field conditions (Carvalho and Moreira, 2010; Marques et al., 2001; Patreze and Cordeiro, 2004; Moreira et al., 2010). The purpose of experiments in non-sterile conditions is to find out whether the inoculated microorganisms are natively competitive with those present in the soil and whether they are adapted to the physical, chemical and biological conditions of this soil or substrate (Moreira et al., 2010). The performance of tests in these conditions presents itself as a challenge to research in facing the great number of variables, which includes competition with other microorganisms present in organic or commercial substrates and which can inhibit the establishment and effectiveness of the inoculated microorganism (Freire et al., 2017; Tavares et al., 2016).

Among several forest legumes used in the reforestation of degraded areas, Tachigali vulgaris (subfamily Caesalpinioideae) is widely used to recover degraded areas due to its rapid growth, reaching $12 \mathrm{~m}$ at 5 years (Dias and Brienza Junior, 1993). It is commonly known as tachi-do-campo or tachi, and also has the synonym Sclerolobium paniculatum, and is associated with NFB (Faria et al., 1989) and AMF (Marinho et al., 2004), being considered a dependent arbuscular mycorrhizae species (Berbara et al., 2006; Telles et al., 1999). It is classified as initial secondary, is endemic to Brazil, and native to the Cerrado, Caatinga and Amazon Forest biomes (Lima, 2015). It occurs on dry land and in sandy, acidic soils with low chemical fertility and well-drained (Dias et al., 1995), not tolerating low temperatures.

Revista Árvore 2020;44:e4424 
In view of the above, the present study aimed to evaluate the effect of inoculation with NFB and AMF on the growth of Tachigali vulgaris seedlings under nursery conditions.

\section{MATERIAL AND METHODS}

The experiment was carried out in the "Terrace" experimental field nursery of Embrapa Agrobiologia, located in Seropédica, RJ $\left(22^{\circ} 45^{\prime} 19.98^{\prime} \mathrm{S}\right.$ and $43^{\circ}$ 40' 04.28 " W, altitude $32 \mathrm{~m}$ ). The region's climate is tropical rainy with a dry winter, being classified as Aw according to the Köppen Classification. The average annual temperature is $23.9^{\circ} \mathrm{C}$, and the average annual precipitation is $1213 \mathrm{~mm}$ (Carvalho et al., 2011).

The tachi seeds used in the experiment were collected from the Embrapa Amapá area in Macapá $\left(0^{\circ} 00^{\prime} 47.77^{\prime} \mathrm{S} ; 51^{\circ} 05^{\prime} 04.50^{\prime} \mathrm{W}, 16 \mathrm{~m}\right.$ altitude) in October 2013. The seeds were immersed in sulfuric acid for $10 \mathrm{~min}$ to break their dormancy, following the recommendations by Carvalho and Figueirêdo (1991).

A completely randomized design in a 3 (NFB strains) x 2 (with and without AMF) factorial scheme was implemented with with three additional control treatments, five repetition, and ten seedlings per repetition, thus totaling 450 seedlings. The tested NFB treatments were: BR 8402 strain (Bradyrhizobium sp.), BR 3637 strain (Ensifer sp.), BR 5610 strain (Bradyrhizobium elkanii), combined with the presence and absence of an inoculant with multiple AMF species. The additional control treatments consisted of seedlings inoculated only with the AMF (TM - mycorrhizal control) and seedlings fertilized only with N (TN nitrogen) or without $\mathrm{N}$ (absolute control - TA).

The inoculants of the bacterial strains were prepared at the Bioprocess Laboratory of Embrapa Agrobiologia using peat as a vehicle, so that there was a minimum 109 CFU g of peat. The inoculation was done by moistening the seeds with distilled water and mixing them with the inoculant until a uniform layer was formed on the seed surface. The seeds were sown directly in the bag in the nursery on the same day of this inoculation.

The mycorrhizal inoculant was prepared at Embrapa Agrobiologia's Mycorrhizal Laboratory. A dose containing approximately 84 spores (4.5 g of inoculant; 12 spores per dose of each species) per container was applied to the sowing hole at the time of planting. The following species were used: Acaulospora colombiana (Spain \&
N.C. Schenck) Kaonongbua, J.B. Morton \& Bever (2010), Acaulospora scrobiculata Trappe (1977), Claroideoglomus etunicatum (W.N. Becker \& Gerd.) C. Walker \& Schuessler (2010), Dentiscutata heterogama (T.H. Nicolson \& Gerd.) Sieverd., F.A. Souza \& Oehl (2008), Gigaspora margarita W.N. Becker \& I.R. Hall (1976), Rhizoglomus clarum (T.H. Nicolson \& N.C. Schenck) Sieverd., G.A. Silva \& Oehl (2014) and Scutellospora calospora (T.H. Nicolson \& Gerd.) C. Walker and F.E. Sanders (1986). All were from the Johanna Döbereiner Biological Resources Center (CRB-JD).

Plastic bags of $12 \mathrm{~cm} \mathrm{x} 18 \mathrm{~cm}$ were used as seedling containers and a mixture of sand and vermiculite (1:1; $\mathrm{v}: \mathrm{v})$ as substrate. Chemical analysis of the substrate was carried out at Embrapa Agrobiologia, collecting three samples. A nutrient solution containing macro $(\mathrm{KCl}$, $\left.\mathrm{CaCl}_{2}, \mathrm{KH}_{2} \mathrm{PO}_{4}, \quad \mathrm{MgSO}_{4} .7 \mathrm{H}_{2} \mathrm{O}\right)$ and micronutrients $\left(\mathrm{H}_{3} \mathrm{BO}_{3} ; \quad \mathrm{MnSO}_{4}, \quad \mathrm{ZnSO}_{4} \cdot 7 \mathrm{H}_{2} \mathrm{O}, \quad \mathrm{CuSO}_{4} .5 \mathrm{H}_{2} \mathrm{O}\right.$, $\mathrm{Na}_{2} \mathrm{MoO}_{4} \cdot 2 \mathrm{H}_{2} \mathrm{O}$ ) was applied to all seedlings (all treatments) every two weeks, following a solution recommendation for pots according to Leonard de Norris, modified to half the salt concentration (Gruzmán and Döbereiner, 1968).

TN seedlings received $8 \mathrm{mg}$ of nitrogen per seed in the form of ammonium nitrate weekly to compare the efficacy of the inoculated bacteria on the mineral source of N. Thus, a total of $308 \mathrm{mg}$ of $\mathrm{N}$ per seedling after 270 days of the experiment. The absolute control did not receive any type of inoculant or mineral fertilizer from $\mathrm{N}$.

The following variables were then measured 270 days after the experiment was implemented: height, stem diameter (SD), shoot dry mass (SDM), root dry mass (RDM), nodule dry mass (NDM), and the number of nodules (NN). The height and DD data were obtained from 10 plants at random, and the dry masses and number of nodules from seven plants within each plot.

The shoot $\mathrm{P}$ content was determined according to the methodology presented by Silva (1999). Mycorrhizal colonization was carried out from oven-dried roots at $60{ }^{\circ} \mathrm{C}$, being rehydrated with $2 \%$ glycerin and heating at $90{ }^{\circ} \mathrm{C}$ for $30 \mathrm{~min}$, then leaving them for 12 hours in water. Samples of the fine roots were clarified after rehydration according to the method used by Koske and Gemma (1989), and the staining according to Grace and Stribley (1991), while the mycorrhizal colonization rate was estimated by the gridline intersect method in checkered plates by Giovannetti and Mosse (1980).

Revista Árvore 2020;44:e4424 
The plant response to mycorrhization was calculated according to the formula of Plenchette et al. (1983). The efficiency and efficacy of bacterial inoculation were determined using the following formulas: efficiency $=$ shoot dry matter of the inoculated treatment/shoot dry matter of the absolute control) $\times 100$; efficacy $=$ (shoot dry matter of the inoculated treatment/shoot dry matter of the nitrogenous control) x 100 .

The data were tested for normality and homogeneity of variance by the Shapiro Wilk and Bartlett tests at 5\% probability, with the mycorrhizal colonization percentage being transformed into arcsen (square root $(\mathrm{x} / 100))$. The analysis of variance for the characteristics and the Scott Knott test were performed at 5\% probability to compare the treatment means using the Sisvar (Ferreira, 2011) and R (R Development Core Team, 2018) programs.

\section{RESULTS}

The chemical analysis of the substrate showed the following characteristics: $\mathrm{pH}$ in water $(2: 1)=$ 4.74 \pm 0.02 ; $\mathrm{P}$ and $\mathrm{K}$ (Mehlich I extractor) $=1.75 \pm 0.17$ and $12.42 \pm 0.49 \mathrm{mg} \mathrm{L}^{-1}$; $\mathrm{Ca}, \mathrm{Mg}$ and $\mathrm{Al}(1 \mathrm{M} \mathrm{KCl})=$ $0.16 \pm 0.01 .0 .44 \pm 0.01$ and $1.01 \pm 0.02 \mathrm{cmol}_{\mathrm{c}} \mathrm{dm}^{-3} ; \mathrm{C}$ $\left(0.0667 \mathrm{~mol} \mathrm{~L}^{-1}\right.$ (potassium dichromate extractor) $=1.4$ $\mathrm{g} \mathrm{dm}^{-3} ; \mathrm{H}+\mathrm{Al}\left(0.5 \mathrm{~mol} \mathrm{~L}^{-1}\right.$ (calcium acetate extractor) $=3.57 \pm 0.06 \mathrm{cmol}_{\mathrm{c}} \mathrm{dm}^{-3} ; \mathrm{N}$ (Kjeldhal) $=0.02 \pm 0.00 \mathrm{~g}$ $\mathrm{dm}^{-3}$.

The treatments showed a highly significant effect $(p<0.01)$ for all variables evaluated, except for the number of nodules, nodule dry mass and mycorrhizal colonization, which did not differ between treatments. The analysis of variance showed a significant difference for the height, SD, SDM, RDM, and total P variables (Figure 1).

The tachi seedlings performed better when doubly inoculated (with NFB and AMF, regardless of the bacterium) when compared to uninoculated or monoinoculated treatments (absolute control, mycorrhizal control and seedlings inoculated only with NFB), being significantly inferior to the nitrogen control. This difference was observed for the variables height, stem diameter (SD), shoot dry mass (SDM) and root dry mass (RDM) (Figure 1).

The analysis of variance showed a significant interaction between AMF and NFB inoculations for height, showing a difference in efficiency between NFB due to the addition of AMF. The BR 3637 and BR
5610 strains produced taller seedlings when inoculated together with AMF than when inoculated alone (Fig 1B). The same was not verified for the BR 8402 strain, which showed no statistical difference in height between mycorrhizal or non-mycorrhizal plants. For the stem diameter and height variables, the double inoculation favored seedling development when inoculated with BR 8402 and BR 3637 strains, but not with BR 5610 (Fig $1 \mathrm{~A})$.

There was no interaction between AMF and NFB for the SDM and RDM variables, meaning that the double inoculation favored accumulating dry mass, regardless of the bacterial strain, indicating a general benefit promoted by the AMF inoculation in the biological nitrogen fixation process and seedling growth promotion (Figure 1).

Mycorrhizal colonization (MC) ranged from $17.85 \%$ in the nitrogenous control to $48 \%$ in the mycorrhizal control (Table 1). According to Carneiro et al. (1998), these values can be considered low $(<20 \%)$ and medium $(>20 \%$ and $<50 \%)$. There was no statistical difference between treatments for this variable, with the data showing a high coefficient of variance, even with the transformation of the data $(\mathrm{CV}=48.25)$.

A higher $\mathrm{P}$ concentration was observed in the shoot in the nitrogen control $(6.10 \mathrm{mg} /$ plant $)$. The second highest value was in the BR 8402 strain + AMF (2.94 $\mathrm{mg} / \mathrm{plant})$, then the BR 3637 strain + AMF (2.62 mg/ plant) and the mycorrhizal control $(2.61 \mathrm{mg} /$ plant $)$. The other treatments showed values below $2.1 \mathrm{mg} / \mathrm{plant}$ (Figure 1E). The only statistically significant difference was observed in the nitrogen control regarding the other treatments.

The fact that all treatments presented mycorrhizal colonization and nodulation, regardless of inoculation, hid the real quantification of the symbiotic efficiency of AMF and NFB. However, this was expected since it would be difficult to establish native communities in non-sterile conditions. Despite this unfavorable control condition, an efficiency rate of over $200 \%$ was observed for BR 8402 (Table 1). The efficiency and effectiveness of double-inoculated treatments were higher than treatments inoculated with NFB alone. The best results were obtained with the BR8402 strain + AMF, with efficiency and effectiveness values of 248.10 and $34.97 \%$, respectively, but without statistical difference regarding the other strains $+\mathrm{m}$, observed by the shoot

Revista Árvore 2020;44:e4424 


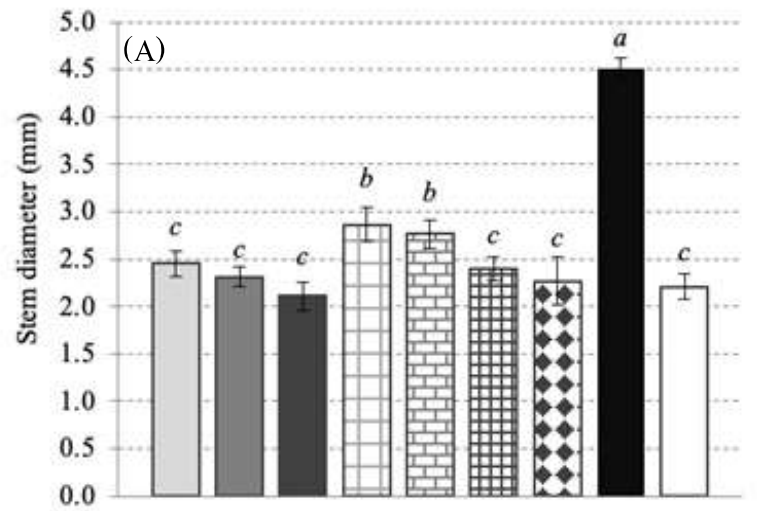

口BR8402

= BR3637

- BR5610

口BR8402 + mycorrhiza

口BR3637 + mycorrhiza

口BR5610 + mycorrhiza

Mycorrhiza

- Nitrogen Control

口Absolute Control
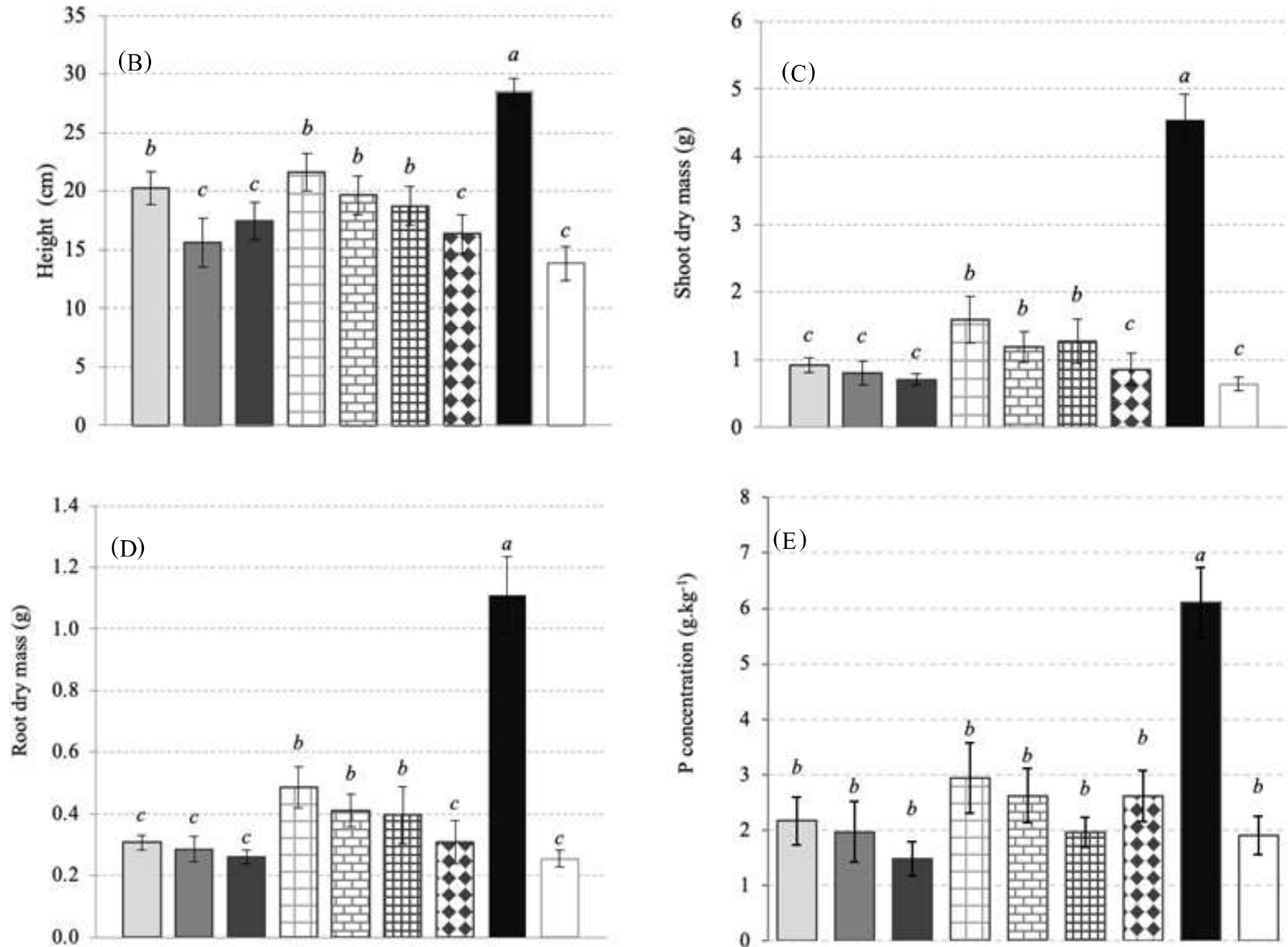

Figure 1 - A-E. Stem diameter, height, shoot dry mass, root dry mass, and P concentration in the shoot of Tachigali vulgaris seedlings inoculated with three $\mathrm{N}_{2}$-fixing bacteria strains combined with arbuscular mycorrhizal fungi inoculant (+ mycorrhiza) and controls without inoculation and without fertilization (absolute), or fertilized with $\mathrm{N}$ after 270 days in a nursery. Averages followed by the same letter do not differ by the Scott Knott test at $5 \%$ probability. The error bar indicates the standard error.

Figura 1 -A-E. Diâmetro a altura do colo, altura, massa seca de parte aérea, massa seca de raiz, concentração de P na parte aérea de mudas de Tachigali vulgaris inoculadas com três estirpes de bactérias fixadoras de $N$ combinadas com inoculante de fungos micorrizicos arbusculares (+ micorrizas) e testemunhas sem inoculação e sem adubaçãa (absoluta) ou adubada com $N$ (nitrogenada) após 270 dias em viveiro. Médias seguidas de mesma letra, por variável, não diferem entre si pelo teste de Scott Knott, a $5 \%$ de probabilidade. A barra de erro indica o erro padrão. 
The double inoculation of tachi seedlings proved to be effective for accelerating their growth, which was reflected in greater height, SD, shoot dry mass (SDM), root dry mass (RDM) and nodule dry mass (NDM). RDM reached $124 \%$ higher values in the treatments with double inoculation regarding the absolute control, and the SDM was up to $90 \%$ higher with double inoculation regarding the seedlings inoculated only with NFB. The plant inoculated with the BR 5610 strain plus AMF showed $207 \%$ higher NDM than the plant inoculated with the strain alone, although this variable has not been statistically differentiated, probably due to the high coefficient of variation $(51.18 \%)$. The double inoculation was no better than the nitrogen control, as expected.

Schiavo and Martins (2003) also observed a positive effect of double inoculation in Acacia mangium Willd seedlings, providing an increase of $54 \%$ in the shoot dry mass regarding the absolute control. Double inoculation in Anadenanthera peregrina var. falcata (Benth.) Altschul. seedlings provided about 60\% greater biomass than the control after ten months (Gross et al., 2004). Marques et al. (2001) verified an increase of $56 \%$ in the dry mass of Centrolobium tomentosum Guillem. ex Benth. plants doubly inoculated compared to uninoculated ones.

It should be emphasized that this does not always happen, as there are cases in which the relationship between these two endosymbionts can generate null or antagonistic effects on plant growth (Xavier and Germida, 2003; Santos et al., 2008), and even colonization of plant nodules by AMF and consequent reduction in NFB in some cases (Carvalho and Moreira, 2010).

The BR 8402 strain + AMF showed efficiency and effectiveness of $248 \%$ and $35 \%$, respectively (Table 1 ). This index is based on the shoot dry mass ratio (\%) of the inoculated plant with that of the absolute control (efficiency) and nitrogen (efficiency). However, it is observed that there was no statistical difference between the shoot dry mass of the three doubly inoculated strains, demonstrating that the joint inoculation of NFB and AMF is generally beneficial for the studied species, regardless of the strain.

The nitrogen control reduced nodule production, but did not completely inhibit it, which may indicate that the dose used of $308 \mathrm{mg}$ of $\mathrm{N}$ per bag of seedling $(1 \mathrm{~kg})$ in this experiment was not sufficient to supply the demand for $\mathrm{N}$ of the species. NFB symbiosis has a considerable cost to the plant in terms of photo-assimilated carbon (C). It is widely documented in the literature that the plant negatively regulates symbiosis with NFB when supplied with high levels of $\mathrm{N}$, and there is additionally feedback control called self-regulation related to nodulation which consists of a process in which the nodule establishment systematically suppresses the subsequent formation of other nodules, preventing the plant from being nodulated indefinitely (Carvalho and Moreira, 2010). The ideal N level found by Simões et al. (2016) for tachi was $150 \mathrm{mg} \mathrm{dm}^{-3}$, even though they did not evaluate the nodulation, and the studied period was only 100 days. A dose of $405 \mathrm{mg} \mathrm{dm}^{-3}$ of $\mathrm{N}$ would be necessary for seedlings of 270 days (which was the case of the present study), considering the linear growth of the species.

The $18-48 \%$ values of mycorrhizal colonization found in the present study were lower than those of other studies developed for this species which found more than $60 \%$ of mycorrhizal colonization (Caldeira et al., 1999; Marinho et al., 2004). This suggests that the inoculated fungi were not totally efficient for tachi or did not perfectly adapt to the substrate. However, very low rates of colonization for some plants are sufficient to promote good development, so that the colonization percentage does not directly and linearly reflect the efficiency of mycorrhizal symbiosis, as it is greatly altered by time and other factors which regulate the mycorrhizae development (McGonigle, 2001; Kiriachek et al., 2009).

The colonization percentage can also be affected by factors such as $\mathrm{P}$ content available in the substrate, plant age, soil $\mathrm{pH}$, root density, AMF propagules in the soil, mycorrhizal dependence on the plant species, nitrogen concentration in the soil, and soil management, among others (Duponnois et al., 2008). The $\mathrm{pH}$ of 4.7 found in the vermiculite sand substrate used in the experiment can be considered low for the development of some AMF species (Wang et al., 1993). Very acidic soils can interfere with the spore germination, the growth of the germ tube and the colonization of arbuscularvesicular mycorrhizal fungi roots, with this influence being variable according to the fungus species (Siqueira et al., 1984). The Glomeraceae group, formed by the Glomus, Funneliformis, and Rhizoglomus genera, is more affected by soils with $\mathrm{pH}$ below 6.5 compared to the Gigasporaceae group, formed by the Gigaspora, Dentiscutata, and Scutellospora genera (Stürmer et al., 2018).

\section{Revista Árvore 2020;44:e4424}


Tachi is considered a species with high mycorrhizal dependence, and it would be expected that it would not be able to develop in the absence of mycorrhizal fungi, and that it would also stop responding to mycorrhization only when the availability of phosphorus $(\mathrm{P})$ was very high (Berbara et al., 2006). Teles et al. (1999) found that AMF inoculation favored an accumulation of total dry matter in the tachi and nodulation up to the dose of $40 \mathrm{mg}$ of $\mathrm{P}$ $\mathrm{kg}^{-1}$ and $80 \mathrm{mg}$ of $\mathrm{P} \mathrm{kg}^{-1}$, respectively. The mycorrhizal or non-mycorrhizal seedlings were equal in growth after this dosage, and this experiment was evaluated up to 140 days. Dias et al. (1995) observed a critical P level of 26.10 $\mathrm{mg} \mathrm{dm}^{-3}$ of substrate for this species. In the present work, $50 \mathrm{mg}$ of $\mathrm{P}$ per seedling in the form of dipotassium and monopotassium phosphate over 270 days in the form of a nutrient solution was applied to a substrate which contained $1.7 \mathrm{mg} \mathrm{L}^{-1}$. The applied amount of $\mathrm{P}$ may have contributed to inhibiting colonization given the low nutritional requirement of the species. Other species which have intermediate mycorrhizal dependence, such as Mimosa artemisiana Heringer \& Paula, fail to respond to inoculation when the available $\mathrm{P}$ (Mehlich I extractor) in the soil is greater than $187 \mathrm{mg} \mathrm{kg}^{-1}$ and has a greater response to AMF inoculation with $\mathrm{P}$ available (Mehlich I extractor) in the soil of $56 \mathrm{mg} \mathrm{kg}^{-1}$ (Hentz et al., 2013). Burity et al. (2000) observed that the addition of $40 \mathrm{~kg}$ $\mathrm{ha}^{-1}$ of P for Mimosa caesalpiniifolia Benth. increased the AMF colonization of roots. Chaves et al. (1995) observed that the addition of $200 \mathrm{mg} \mathrm{dm}^{-3} \mathrm{P}$ did not affect colonization for Dalbergia nigra (Vell.) Fr.All. ex Benth.

Recent studies have indicated that mycorrhizaldependent species such as Piptadenia gonoacantha (Mart.) J. F. Macbr. and Acacia holosericea A.Cunn. ex G.Don. nodulate in the absence of AMF, but the nodules are not efficient in absorbing atmospheric $\mathrm{N}$ (Bournaud et al., 2018; Oliveira Júnior et al., 2017; Duponnois et al., 2008). These same studies indicate that mycorrhizal colonization is dependent on rhizobia, and the efficacy of the nodule and plant growth are dependent on the presence of specific combinations of rhizobia strains and AMF. Although the present study did not go into methodological depth in evaluating the efficacy of the nodule, it still corroborates this evidence by verifying a significant gain in the dry mass of the double inoculated treatments, and therefore confirming the need to produce seedlings with both symbionts. It is suggested that new strains of bacteria be tested, preferably isolated from tachi roots in their natural habitat, since the strains used herein were not collected from the natural biome of this tree, and there may be even more gains with speciesspecific bacteria, and the same gain could be obtained with a selection of AMF strains for this tree.

\section{CONCLUSIONS}

Tachigali vulgaris grows better when inoculated with rhizobia and mycorrhizal fungi than when inoculated alone with one of these symbionts.

The positive effect of double inoculation occurred regardless of the bacteria strain used.

\section{REFERENCES}

Berbara RLL, Souza FA, Fonseca HMAC. IIIFungos micorrízicos arbusculares: muito além da nutrição. In: Fernandes MS, editor. Nutrição mineral de plantas. Viçosa, MG: Sociedade Brasileira de Ciência do Solo; 2006. p. 74-85.

Bournaud C, James EK, Faria SM, Lebrun M, Melkonian R, Duponnois R, et al. Interdependency of efficient nodulation and arbuscular mycorrhization in Piptadenia gonoacantha, a Brazilian legume tree. Plant, Cell \& Environment. 2018;41(9):2008-20. doi: 10.1111/pce. 13095

Burity HA, Lyra MCCP, Souza ES, Mergulhão ACES, Silva MLRB. Efetividade da inoculação com rizóbio e fungos micorrízicos arbusculares em mudas de sabiá submetidas a diferentes níveis de fósforo. Pesquisa Agropecuária Brasileira. 2000;35(4):801-07.

Caldeira MVW, Silva EMR, Franco AA, Zanon MLB. Efeito de fungos micorrízicos arbusculares no desenvolvimento de duas leguminosas arbóreas. Ciência Florestal. 1999;9(1):63-70. doi: https://doi. org/10.5902/19805098366

Carneiro MAC, Siqueira JO, Moreira FMS, Carvalho D, Botelho SA, Saggin-Junior OJ, et al. Micorriza arbuscular em espécies arbóreas e arbustivas nativas de ocorrência no sudeste do Brasil. Cerne. 1998;4(1):129-45.

Carpanezzi AA, Marques LCT, Kanashiro M. Aspectos ecológicos e silviculturais de taxi-branco-da-terrafirme (Sclerolobium paniculatum). Circular Técnica, 8.Curitiba: EMBRAPA-URPFCS; 1983. 10 p.

Revista Árvore 2020;44:e4424 
Carvalho JEU, Figueirêdo FJC. Biometria e métodos para superação da dormência de sementes de taxibranco, Sclerolobium paniculatum Vogel. Boletim de Pesquisa, 114. Belém, PA: Embrapa Amazônia Oriental, CPATU; 1991. 18 p.

Carvalho TS, Moreira FMS. Simbioses tripartites leguminosas-fungos micorrízicos e bactérias fixadoras de nitrogênio nodulíferas. In: Siqueira JO, Souza FA, Cardoso EJBN, Tsai SM. Micorrizas: 30 anos de pesquisas no Brasil. Lavras, MG: UFLA; 2010. p. 383-413.

Carvalho DF, Silva DG, Souza AP, Gomes DP, Rocha HS. Coeficientes da equação de AngströmPrescott e sua influência na evapotranspiração de referência em Seropédica, RJ. Revista Brasileira de Engenharia Agrícola. 2011;15(8):108-16.

Chaer GM, Resende AS, Campello EFC, Faria SM, Boddey RM. Nitrogen-fixing legume tree species for the reclamation of severely degraded lands in Brazil. Tree Physiology. 2011;31(2):139-49. doi: https://doi. org/10.1093/treephys/tpq116

Chaves LFC, Borges RCG, Neves JCL, Regazzi AJ. Crescimento de mudas de jacarandá-da-bahia (Dalbergia nigra (Vell.) Fr. Allem) em resposta a inoculação com fungos micorrízicos vesículoarbusculares em diferentes níveis de fósforo no solo. Revista Árvore. 1995;19(1):32-49.

Dias LE, Franco AA, Campello E, Faria SM, Silva EM. Leguminosas forestales: aspectos relacionados com su nutrición y uso en la recuperación de suelos degradados. Bosque. 1995;16(1):121-27.

Dias LE, Brienza Junior S. Sclerolobium paniculatum Vogel: uma leguminosa arbórea nativa da Amazônia com potencial para recuperar áreas de solos degradados. In: Simpósio Internacional de Manejo e Reabilitação de Áreas Degradadas. 1993; Santarém, PA.

Döbereiner J. Nodulação e fixação de nitrogênio em leguminosas florestais. Pesquisa Agropecuária Brasileira. 1984;19:83-90.

Duponnois R, Kisa M, Prin Y, Ducousso M, Plenchette C, Lepage M, et al. Soil factors influencing the growth response of Acacia holosericea A. Cunn. ex G. Don to ectomycorrhizal inoculation. New Forests. 2008;35(2):105-17.
Faria ABC, Monteiro PHR, Auer CG, Ângelo AC. Uso de ectomicorrizas na biorremediação florestal. Ciência Florestal. 2017;27(1):21-29.

Faria SM, Lewis GP, Sprent JI, Sutherland JM. Occurrence of nodulation in the Leguminosae. New Physiologist. 1989;111(4):607 -19.

Ferreira DF. Sisvar: a computer statistical analysis system. Ciência e Agrotecnologia. 2011;35(6):1039-42.

Franco AA, Dias LE, Campello EFC, Silva EMR, Faria SM. Uso de leguminosas florestais noduladas e micorrizadas como agentes de recuperação e manutenção da vida no solo: um modelo tecnológico. In: Esteves F, editor. Oecologia Brasilienses. Rio de Janeiro: UFRJ; 1995. p. 459-67.

Freire JM, Jesus EC, Rouws JRC, Faria SM, Zilli JE. Efeito do substrato sobre o crescimento de mudas de Mimosa bimucronata inoculadas com estirpes de rizóbio. Pesquisa Florestal Brasileira; 2017;37(90):131-38.

Giovannetti M, Mosse B. An evaluation of techniques to measure vesicular- arbuscular mycorrhizal infection in roots. New Phytologist. 1980;84(3):489-90.

Grace C, Stribley DP. A safer procedure for routine staining of vesicular-arbuscular mycorrhizal fungi. Mycological Research. 1991;95(10):1160-62.

Gross E, Cordeiro L, Caetano FH. Nodulação e micorrização em Anadenanthera peregrina var. falcata em solo de cerrado autoclavado e não autoclavado. Revista Brasileira de Ciência do Solo. 2004;28(1):95-101.

Gruzmán I, Döbereiner J. Effect of Azotobacter chroococcum and tryptophan on the inoculation of soybean (Glycine max (L.) Merr.) with Rhizobium japonicum. In: Reunião latino americana sobre inoculantes para legum, 4, Anais; 1968. Porto Alegre: Secretaria de Agricultura; 1968. p. 46-57.

Hentz AM, Silva EMR, Saggin Júnior OJ. Dependência micorrízica da leguminosa Mimosa artemisiana Heringer \& Paula. Revista Agroecossistemas. 2013;4(2):67-78.

Revista Árvore 2020;44:e4424 
Kiriachek SG, Azevedo LCB, Peres LEP, Lambais MR. Regulação do desenvolvimento de micorrizas arbusculares. Revista Brasileira de Ciência do Solo. 2009;33(1):1-16.

Koske RE, Gemma JN. A Modified procedure for staining roots to detect VA mycorrhizas. Mycological Research. 1989;92(4):488-505.

Lima HC. Tachigali. In: Lista de Espécies da Flora do Brasil. Jardim Botânico do Rio de Janeiro. 2015. Disponível em: <http://floradobrasil.jbrj.gov.br/jabot/ floradobrasil/FB100914>. Acesso: 01 Mar. 2018.

Marinho NF, Caproni AL, Franco AA, Berbara RLL. Respostas de Acacia mangium Willd e Sclerolobium paniculatum Vogel a fungos micorrízicos arbusculares nativos provenientes de áreas degradadas pela mineração de bauxita na Amazônia. Acta Botanica Brasilica. 2004;18(1):141-49.

Marques MS, Pagano M, Scotti MRMML. Dual inoculation of a woody legume (Centrolobium tomentosum) with rhizobia and mycorrhizal fungi in south-eastern Brazil. Agroforestry Systems. 2001;52(2):107-17.

McGonigle TP. On the use of non-linear regression with the logistic equation for changes with time of percentage root length colonized by arbuscular mycorrhizal fungi. Mycorrhiza. 2001;10(5):249-54.

Moreira FMS, Faria SM, Balieiro FC, Florentino LA. Bactérias fixadoras de N2 e fungos micorrízicos arbusculares em espécies florestais: avanços e aplicações biotenológicas. In: Figueiredo MVB, Burity HA, Oliveira JP, Santos CERS, Stamford NP, editores. Biotecnologia aplicada à agricultura: textos de apoio e protocolos experimentais. Brasília, DF: Embrapa Informação Tecnológica; Recife, PE: Instituto Agronômico de Pernambuco (IPA); 2010. p. 439-477.

Oliveira Júnior JQ, Jesus EC, Lisboa FJ, Berbara RLL, Faria SM. Nitrogen-fixing bacteria and arbuscular mycorrhizal fungi in Piptadenia gonoacantha (Mart.) Macbr. Brazilian Journal of Microbiology. 2017;48(1):95-100.

Patreze CM, Cordeiro L. Nitrogen-fixing and vesicular-arbuscular mycorrhizal symbioses in some tropical legume trees of tribe Mimoseae. Forest Ecology and Management. 2004;196(2-3):275-85.
Peoples MB, Brockwell J, Herridge DF, Rochester IJ, Alves BJR, Urquiaga S, et al. The contributions of nitrogen-fixing crop legumes to the productivity of agricultural systems. Symbiosis. 2009;48(1-3):1-17.

Plenchette C, Fortin JA, Furlan V. Growth responses of several plant species to mycorrhizae in a soil of moderate P-fertility. Plant and Soil. 1983;70(2):199-209.

Pouyu-Rojas E, Siqueira JO, Santos JGD. Compatibilidade simbiótica de fungos micorrízicos arbusculares com espécies arbóreas tropicais. Revista Brasileira de Ciência do Solo. 2006;30(3):413-24.

R Development Core Team. R: A language and environment for statistical computing. Vienna, Austria: R Foundation for Statistical Computing; 2018. Available from: <URL https://www.R-project.org/>.

Saggin-Junior OJ, Silva EMR. Micorriza Arbuscular: papel, funcionamento e aplicação da simbiose. In: Aquino AM, Assis RL, ed. Processos Biológicos no Sistema Solo-Planta. Brasília: Embrapa Informação Tecnológica; 2005. p.101-149.

Santos DR, Costa MCS, Miranda JRP, Santos RV. Micorriza e rizóbio no crescimento e nutrição em N e P de mudas de angico-vermelho. Revista Caatinga. 2008;21(1):76-82.

Schiavo JA, Martins MA. Produção de mudas de acácia colonizadas com micorrizas e rizóbio em diferentes recipientes. Pesquisa Agropecuária Brasileira. 2003;38(2):173-78.

Silva FC. Manual de análises químicas de solos, plantas e fertilizantes. Brasília: Embrapa Comunicação para Transferência de Tecnologia; 1999. $370 \mathrm{p}$.

Simões PHO, Oliveira Neto CF, Vale RS, Palheta LF, Paula MT. Crescimento e qualidade de mudas de Tachigali vulgaris L.G. Silva \& H.C. Lima em resposta à fontes e doses de nitrogênio. Espacios. 2016;37(38):29.

Siqueira JO, Hubbell DH, Mahmud AW. Effect of liming on spore germination, germ tube growth and root colonization by vesiculararbuscular mycorrhizal fungi. Plant and Soil.

Revista Árvore 2020;44:e4424 
$1984 ; 76(1-3): 115-24$.

Smith SE, Smith FA. Roles of Arbuscular Mycorrhizas in Plant Nutrition and Growth: New Paradigms from Cellular to Ecosystem Scales. Annual Review of Plant Biology. 2011;62(1):227-50.

Stürmer SL, Oliveira LZ, Morton JB.

Gigasporaceae versus Glomeraceae (phylum Glomeromycota): a biogeographic tale of dominance in maritime sand dunes. Fungal Ecology. 2018;32:49-56.

Tavares SRL, Franco AA, Silva EMR. Produção de mudas de sabiá Mimosa caesalpiniaefolia Benth noduladas e micorrizadas em diferentes substratos. Holos. 2016;7:231-41.

Teles CS, Silva MF, Souza FA, Franco AA. Influência da inoculação com fungos micorrízicos e níveis crescentes de $\mathrm{P}$ no crescimento inicial do taxi dos campos (Sclerolobium paniculatum Vog). Comunicado Técnico. 1999;34:1-4.

Travis AS. Globalising synthetic nitrogen: the interwar inauguration of a new industry. Ambix. 2017;64(1):1-28.

Wagg C, Jansa J, Stadler M, Schmid B, Van Der Heijden MGA. Mycorrhizal fungal identity and diversity relaxes plant-plant competition. Ecology. 2011;92(6):1303-13.

Wang GM, Stribley DP, Tinker PB, Walker C. Effects of $\mathrm{pH}$ on arbuscular mycorrhiza I. Field observations on the long-term liming experiments at Rothamsted and Woburn. New Phytologist. 1993;124(3):465-72.

Xavier LJC, Germida JJ. Selective interactions between arbuscular mycorrhizal fungi and Rhizobium leguminosarum bv. viceae enhance pea yield and nutrition. Biology and Fertility of Soils. 2003;37(5):261-67. 